Agric. Biol. Chem., 41 (3), 445 450, 1977

\title{
Formation of Protein-like Activator for $n$-Alkane Oxidation and Its Properties
}

\author{
Kenichi Hisatsuka, * Tadaatsu Nakahara, Yasuji Minoda \\ and Koichi YAMADA \\ Department of Agricultural Chemistry, The University of Tokyo \\ Received June 14, 1976
}

\begin{abstract}
"Protein-like activator (PA)" for $n$-alkane oxidation was formed by Pseudomonas aeruginosa $\mathrm{S}_{7} \mathrm{~B}_{1}$ from long-chain $n$-alkanes, 1 -hexadecene and cetyl alcohol but not from glucose, glycerol and palmitic acid. The molecular weight and the total amino acid residues of PA were estimated at about 14,300 and 147 , respectively. PA was relatively stable to low $\mathrm{pH}$ and high temperature, and completely inactivated upon heating at $98^{\circ} \mathrm{C}$ for $45 \mathrm{~min}$. The cultural fluid obtained from $n$-hexadecane medium stimulated the growth of the strain on $n$-hexadecane. The degree of the growth stimulation by the fluid depended on the amount of PA and rhamnolipid (RL) in the fluid. The heat-treated PA lost the growth-stimulaing effect and the emulsifying power on the $n$-hexadecane medium in the presence of RL.
\end{abstract}

Two kinds of activators for $n$-alkane oxida-

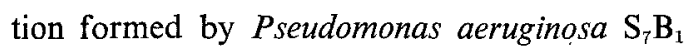
were isolated and their role on $n$-alkane oxidation was previously reported. ${ }^{1,2)}$ One of them, which was termed "protein-like activator (PA)" was purified to a homogeneous state as judged by cellulose acetate membrane electrophoresis.

In the preceding paper, ${ }^{31}$ the authors reported that the oxidation capacity of the strain was reduced by treatment with EDTA on the oxidation of long-chain $n$-alkanes and the reduced capacity to oxidize these substrates was restored to the level of the non-treated cells with PA. In terms of the PA activity on EDTAtreated cells, it became possible to determine PA in the cultural fluid and to investigate the properties of PA.

The present paper deals with the amount of PA formed from various carbon sources, the amino acid composition and some properties of PA and the stimulating effect of PA on the growth of the strain on $n$-hexadecane.

\section{MATERIALS AND METHODS}

Cultivation of microorganisms and preparation of EDTA-treated cells. Ps. aeruginosa $\mathrm{S}_{7} \mathrm{~B}_{1}$ was employ-

* Present address: Central Research Laboratory, Idemitsu Kosan Co., Ltd., Kimitsu-gun, Chiba-ken, Japan. ed throughout this investigation. The basal medium, the condition of cultivation and the preparation of EDTA-treated cells were described in the previous paper. ${ }^{3)}$

Determination of cell growth. Absorbance of the cultures was measured at $660 \mathrm{~nm}$ with a Spectronic 20 spectrometer (Shimadzu Co.) according to our method. ${ }^{4)}$

Determination of PA. Method I. Thirty $\mathrm{ml}$ of the supernatant of the culture broth was brought to $70 \%$ saturation with ammonium sulfate with constant and slow stirring. After standing overnight at $5^{\circ} \mathrm{C}$ the mixture was centrifuged at $10,000 \times g$ for $10 \mathrm{~min}$ and the supernatant was discarded. The precipitate was dissolved in a small amount of distilled water and dialyzed against running tap water for $24 \mathrm{hr}$, followed by dialysis against $0.01 \mathrm{M} \mathrm{Na} \mathrm{HPO}_{4}$ for $24 \mathrm{hr}$. The dialyzed solution was filled up to $5 \mathrm{ml}$ with $0.01 \mathrm{M}$ $\mathrm{Na}_{2} \mathrm{HPO}_{4}$ and placed on a column of DEAE-Sephadex A-50 $(0.8 \times 15 \mathrm{~cm})$, which had been equilibrated with $0.01 \mathrm{M} \mathrm{Na} \mathrm{NPO}_{4}$. The elution was carried out with the same solution. The first $5 \mathrm{ml}$ of the eluate was discarded and the next $20 \mathrm{ml}$ of the eluate was collected. PA activity of the eluate collected was measured by the Warburg technique as described in the previous paper. ${ }^{83}$ PA was determined by the calculation on the basis of the restoration effect of PA on $n$-hexadecane oxidation capacity in EDTA-treated cells.

Method II. Four $\mathrm{ml}$ of the supernatant of the culture broth was dialyzed against running tap water for $24 \mathrm{hr}$, followed by dialysis against $0.01 \mathrm{M} \mathrm{Na}_{2} \mathrm{HPO}_{4}$ for $24 \mathrm{hr}$. The dialyzed solution was placed on a column of DEAE-Sephadex A-50 $(0.8 \times 15 \mathrm{~cm})$, which had been equilibrated with $0.01 \mathrm{M} \mathrm{Na} \mathrm{HPO}_{4}$. The first $4 \mathrm{ml}$ of 
the eluate was discarded and the next $10 \mathrm{ml}$ of the eluate was collected. PA was determined by the same method as described above.

Determination of rhamnolipid $(R L)$. The amount of $\mathrm{RL}$ produced in the culture broth was colorimetrically determined by the anthrone method as follows.

Cells were centrifuged off at $10,000 \times g$ for $10 \mathrm{~min}$ and discarded. Two $\mathrm{ml}$ of the supernatant or the diluted solution was adjusted to $\mathrm{pH} 2.0$ with $1 \mathrm{~N} \mathrm{HCl}$ and extracted twice with $10 \mathrm{ml}$ of ethyl acetate. The extract was evaporated to dryness under reduced pressure. The residue was dissolved in a small amount of diethyl ether and was poured into a test tube. After the addition of 2 drops of methanol, $0.5 \mathrm{ml}$ of distilled water and $5 \mathrm{ml}$ of anthrone reagent, ${ }^{57}$ the mixture was heated in boiling water for $3 \mathrm{~min}$, cooled in running tap water. Absorbance of the solution at $630 \mathrm{~nm}$ was measured with a Spectronic 20 spectrometer.

Ultracentrifugal analysis. Ultracentrifugal analysis of PA was performed with a Hitachi model UCA-1 ultracentrifuge equipped with a Schlieren optical system.

Estimation of molecular weight. The molecular weight of PA was determined by the method of Andrews, ${ }^{\text {B) }}$ using a Sephadex G-75 column and several standard proteins.

Amino acid composition. The hydrolysis of PA was carried out with $6 \mathrm{~N} \mathrm{HCl}$ in a sealed tube in vacuo at $110^{\circ} \mathrm{C}$ for 24,48 and $72 \mathrm{hr}$, respectively. The hydrolyzate was subjected to chromatographic analysis with an automatic amino acid analyzer. The cysteine content was determined by analyzing cysteic acid in a sample oxidized with performic acid. ${ }^{\text {T) }}$ The tryptophan content was determined by a spectrophotometric method $^{8)}$ and the $p$-dimethylaminobenzaldehyde method. ${ }^{a)}$

Determination of protein concentration. Protein concentration was determined by the method of Lowry et al, as described previously ${ }^{27}$ and expressed as a human albumin equivalent.

\section{RESULTS AND DISCUSSION}

Effect of carbon sources on the formation of $P A$ Table I shows the amount of PA formed from various carbon sources. PA was formed from longer-chain $n$-alkanes and 1-hexadecene in larger quantities and from $n$-tridecane and cetyl alcohol in smaller quantities, but not from glucose, glycerol and palmitic acid. It is interesting that PA is formed not only from n-
Table I. EFfect of Carbon Sources on THE ForMation OF PA

A spoonful cells grown on $n$-hexadecane slant was inoculated. The cultivation was carried out until stationary phase at $30^{\circ} \mathrm{C}$ in a shaking flask $(500 \mathrm{ml})$ containing $50 \mathrm{ml}$ of the basal medium and each carbon source. The amount of PA was determined according to METHOD I.

\begin{tabular}{lccc}
\hline Carbon source & $\begin{array}{c}\text { Cultivation } \\
\text { time } \\
(\mathrm{hr})\end{array}$ & $\begin{array}{c}\text { Growth } \\
(\mathrm{OD} \text { at } \\
660 \mathrm{~nm})\end{array}$ & $\begin{array}{c}\text { PA } \\
\left(\mu \mathrm{g}^{a}\right) \\
\mathrm{ml})\end{array}$ \\
\hline $1 \%(\mathrm{w} / \mathrm{v})$ glucose & 14 & 0.74 & 0 \\
$2 \%(\mathrm{w} / \mathrm{v})$ glycerol & 32 & 0.65 & 0 \\
$1 \%$ (w/v) palmitic acid & 14 & 0.76 & 0 \\
$1 \%(\mathrm{w} / \mathrm{v})$ cetyl alcohol & 27 & 0.69 & 30 \\
$1 \%(\mathrm{v} / \mathrm{v})$ 1-hexadecene & 88 & 0.75 & 80 \\
$" \quad$ n-tridecane & 88 & 0.72 & 50 \\
$" \quad$ n-tetradecane & $"$ & 0.75 & 70 \\
$" \quad$ n-pentadecane & $"$ & 0.71 & 100 \\
$" \quad n$-hexadecane & $"$ & 0.74 & 100 \\
$" \quad$ n-heptadecane & $"$ & 0.75 & 110 \\
$" \quad n$-octadecane & $"$ & 0.73 & 120 \\
\hline
\end{tabular}

a) Human serum albumin equivalent.

alkanes but also cetyl alcohol and 1-hexadecene. As shown in Table I, the amount of PA increases as the chain-length of $n$-alkane increases. This fact indicates that the formation of PA relates to the hydrophobic property of the carbon source.

Time course of the formation of $P A$ and $R L$ from n-hexadecane

As shown in Fig. 1, the formation of PA was associated with the growth until the middle phase of the growth. RL isolated from the culture broth of the strain as a growth stimulant on $n$-hexadecane medium ${ }^{10}$ ' was formed little in the initial phase of the growth.

When RL or PA is added to the medium from the start of the cultivation, $\mathrm{RL}$ is more effective on the growth of Ps. aeruginosa $\mathrm{S}_{7} \mathrm{~B}_{1}$ than $\mathrm{PA}^{2}{ }^{2}$ But from the result of Fig. 1, it can be presumed that PA plays a more important role in the initial growth of the strain on $n$-hexadecane.

\section{Homogeneity of the purified $P A$}

PA was purified by ammonium sulfate precipitation and chromatography on DEAESephadex A-50, CM-Sephadex C-50 and Sephadex G-75 columns according to the pre- 


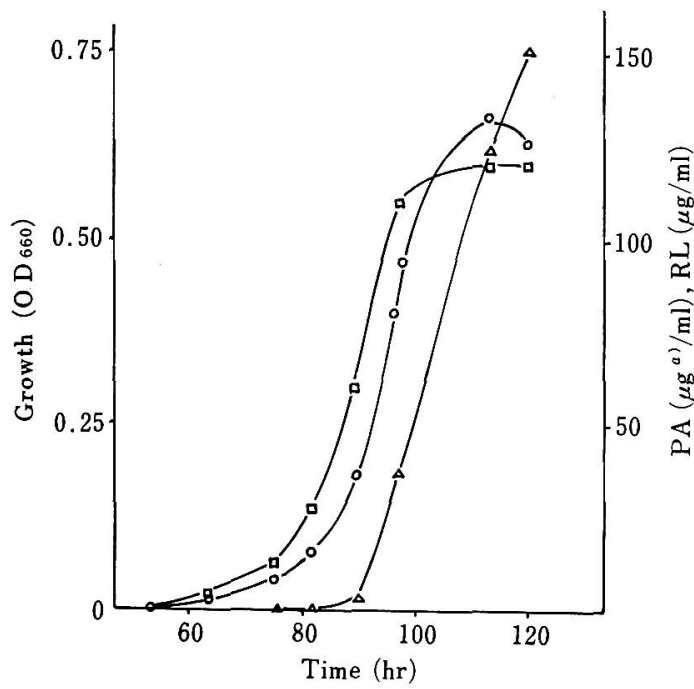

FIg. 1. Time Course of the Formation of PA and RL from $n$-Hexadecane.

The conditions of the cultivation were described in the legend of Table I. The amount of PA was determined according to MerHoD II.

Carbon source: $1 \%(\mathrm{v} / \mathrm{v}) n$-hexadecane.

$\mathrm{O}-\mathrm{O}$, growth; $\square-\square, \mathrm{PA} ; \triangle-\triangle$, RL.

a) Human serum albumin equivalent.

viously outlined procedure. ${ }^{2)}$

Homogeneity of the purified PA was analyzed by ultracentrifugation and the patterns are shown in Fig. 2. The patterns show a single peak which reveals that the purified PA is homogeneous in ultracentrifugal analysis.

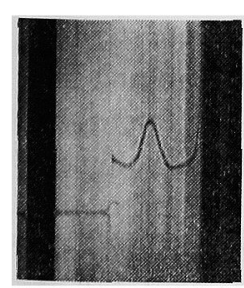

$20 \mathrm{~min}$

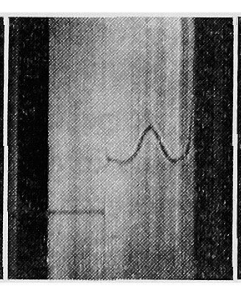

40 min

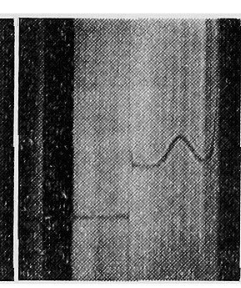

$60 \mathrm{~min}$
Fig. 2. Sedimentation Patterns of PA.

The sample was $1 \%$ solution of $\mathrm{PA}$ in $1 / 15 \mathrm{M}$ phosphate buffer ( $\mathrm{pH} \mathrm{7.0)}$ containing $0.1 \mathrm{M}$ of $\mathrm{KCl}$. The photographs were taken at the indicated times after reaching the full speed $(60,000 \mathrm{rpm})$.

\section{Estimation of molecular weight and amino acid composition of $P A$}

The elution patterns of standard proteins were measured from the optical extinction at
$280 \mathrm{~nm}$ and the peak of PA was determined from its biological activity. From a plot of the molecular weight against the volume of eluates, as shown in Fig. 3, the molecular weight of PA was assumed to be $1.4 \times 10^{4}$ to $1.5 \times 10^{4}$.

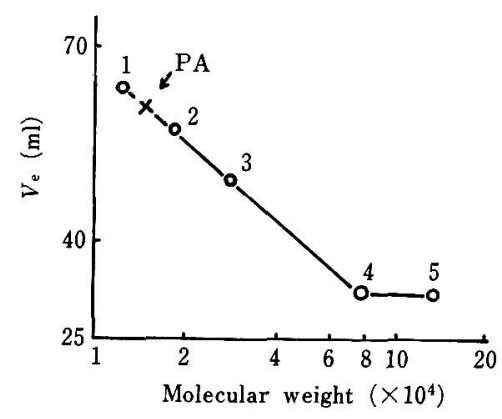

FIG. 3. Estimation of Molecular Weight by Sephadex G-75 Gel Filtration.
1. cytochrome $\mathrm{C}$
2. myoglobin
3. chymotrypsinogen A
4. serum albumin
5. $\gamma$-globulin

Table II shows the amino acid composition of PA and the molecular weight of PA estimated from the amino acid composition. From the results of Table II, the molecular weight of PA and the total amino acid residues were calculated as about 14,300 and 147 , respectively.

The characteristics of the amino acid composition of PA are high contents of serine and threonine residues and the absence of arginine and histidine residues. As shown in Table II, the total amino acid residues account for $102.1 \%$. This high recovery may be due to the absence of other substances than amino acids.

\section{Effect of $p H$ and temperature on the stability of $P A$}

The $\mathrm{pH}$ stability of PA was tested between $\mathrm{pH} 1.3$ and 12.5. PA was incubated at a given $\mathrm{pH}$ for $20 \mathrm{hr}$ and then diluted with $1 / 15 \mathrm{M}$ phosphate buffer ( $\mathrm{pH} 7.0$ ). The residual activity of PA was calculated on the basis of the standard curve of PA concentration vs. $\mathrm{QO}_{2}$ measured by the Warburg method. In order to measure correct activities, the assay was 
TABle II. Amino Acid Composition of PA

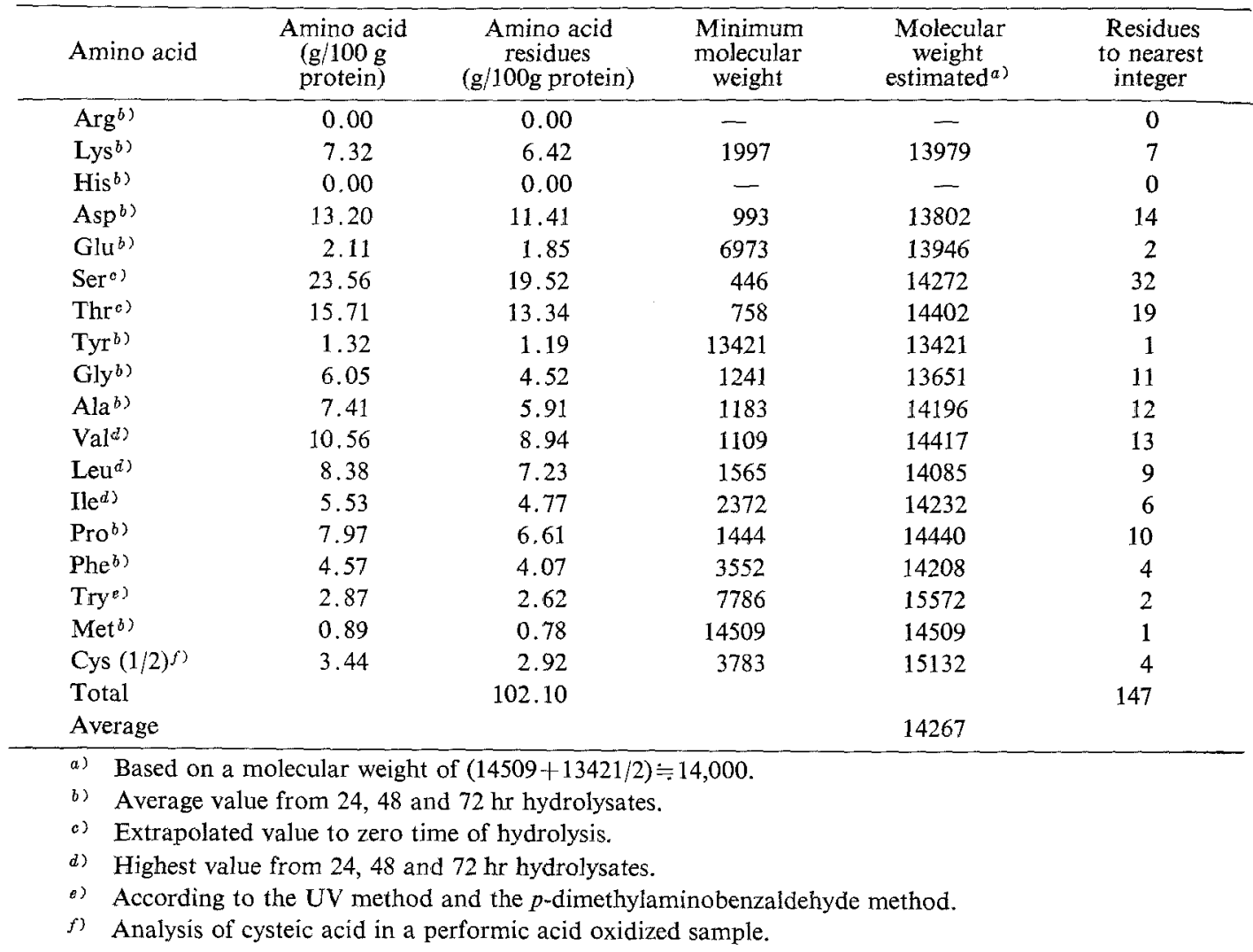

done under the conditions giving approximately a linear relationship between the amount of protein in the sample and $\mathrm{QO}_{2}$, although the situation is not the same as in an enzyme reaction. The results in Fig. 4 indicate that $\mathbf{P A}$ is quite stable in a range between $\mathrm{pH} 1.7$ and 11.4 at $5^{\circ} \mathrm{C}$.

The effect of temperature on the stability of PA was determined by incubating PA at various temperatures for $20 \mathrm{~min}$. From the results in Fig. 5, it is evident that PA is relatively stable to heat and partially destroyed at $98^{\circ} \mathrm{C}$. Figure 6 shows the relationship between the stability of PA and the heating time at $98^{\circ} \mathrm{C}$. PA was completely inactivated by the heating at $98^{\circ} \mathrm{C}$ for $45 \mathrm{~min}$.

As shown in Figs. 4 6, PA is relatively stable to low $\mathrm{pH}$ and high temperature as a protein. Regarding the stability of $\mathrm{PA}$, it is possible that PA is hardly denatured itself or denatured PA is easily renatured.
Effect of $P A, R L$ and cultural fluid on the

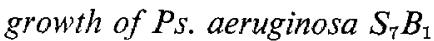

A PA solution and the culture fiuid obtained from the $n$-hexadecane medium by centrifugation at $10,000 \times g$ for $10 \mathrm{~min}$ were sterilized by filtration with a Millipore membrane filter (pore size $=0.22 \mu$ ), respectively. Twenty-five $\mathrm{ml}$ of the fluid blended in an equal volume of the basal medium was used for the cultivation.

As shown in Figs. 7 and 8, PA and RL cooperatively stimulated the growth of the strain, and the degree of the growth stimulation with the cultural fluid depended on the amount of PA and RL contained in the fluid. These results indicate that the growth-stimulating factors in the culture fluid are PA and RL.

Interaction between $P A$ and rhamnolipid on the emulsification of $n$-hexadecane

It is worth noting that the heat-treated PA lost the restration effect on the $n$-hexadecane 


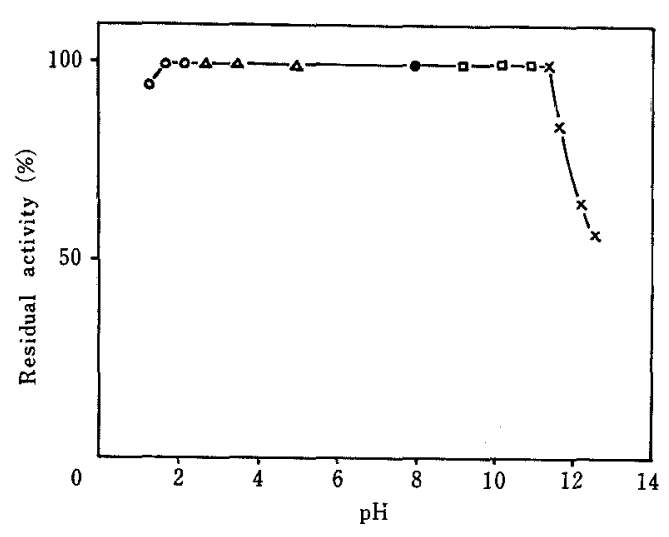

FIG. 4. Effect of $\mathrm{pH}$ on Stability of PA. Buffers used were $0.1 \mathrm{M} \mathrm{HCl}-\mathrm{KCl}(\mathrm{O}), 0.1 \mathrm{M}$ phthalate $(\triangle), 0.1 \mathrm{M}$ phosphate (๑), $0.1 \mathrm{M} \mathrm{NaHCO}_{3}-\mathrm{Na}_{2} \mathrm{HCO}_{3}$ $(\square)$ and $0.1 \mathrm{M} \mathrm{KCl}-\mathrm{NaOH}(\times)$. Equal volumes of a PA solution $\left.\left(320 \mu \mathrm{g}^{a}\right) / \mathrm{ml}\right)$ and buffer were mixed and incubated at $5^{\circ} \mathrm{C}$ for $20 \mathrm{hr}$. After the incubation, the PA solution was suitably diluted with $1 / 15 \mathrm{M}$ phosphate buffer, $\mathrm{pH} 7.0$ and portions of the diluted solution were analyzed for the remaining activity by the Warburg technique as follows.

Each Warburg vessel contained $20 \mu 1$ of $n$-hexadecane, $0.5 \mathrm{ml}$ of an EDTA-treated cell suspension, $1 \mathrm{ml}$ of $1 / 15 \mathrm{M}$ phosphate buffer containiug $160 \mu \mathrm{g}$ of rhamnolipid and $0.5 \mathrm{ml}$ of the diluted PA solution in the main compartment, and $0.3 \mathrm{ml}$ of $10 \% \mathrm{KOH}$ in the center well, to give a total volume of $2.32 \mathrm{ml}$. Incubation was carried out at $30^{\circ} \mathrm{C}$.

The estimation of the residual activity of $\mathrm{PA}$ is described in the text.

a) Human serum albumin equivalent.

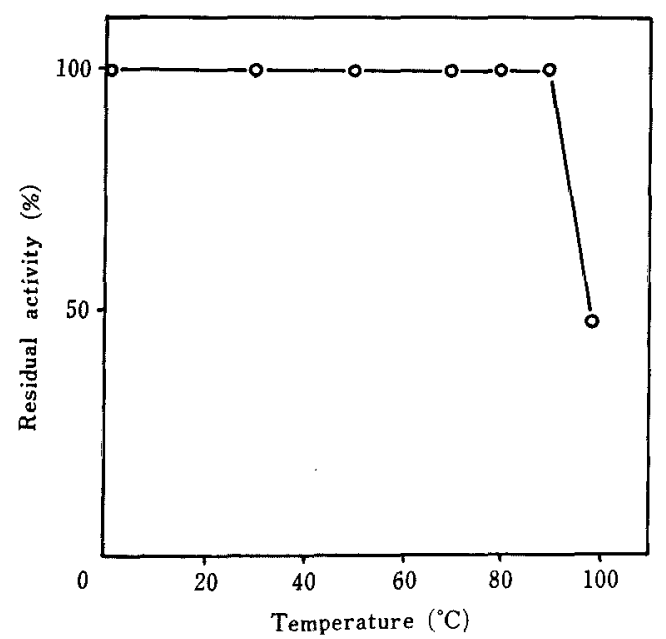

FIG, 5. Effect of Temperature on Stability of PA. Two milligrams of PA was dissolved in $10 \mathrm{ml}$ of $1 / 15 \mathrm{M}$ phosphate buffer, pH 7.0 and this solution was subjected to $20 \mathrm{~min}$ of heat treatment at the temperatures indicated. The residual activity of PA was measured under the same conditions as described in the legend of Fig. 4.

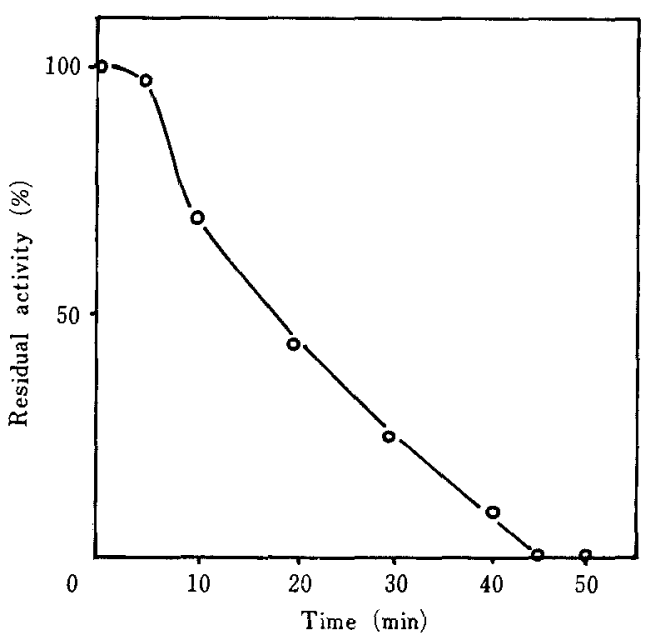

FIG. 6. Heat Inactivation of PA.

Two milligrams of PA was dissolved in $10 \mathrm{ml}$ of $1 / 15 \mathrm{M}$ phosphate buffer, $\mathrm{pH} 7.0$ and this solution was stored at $98^{\circ} \mathrm{C}$ for various times. The residual activity of PA was measured under the same conditions as described in Fig. 4.

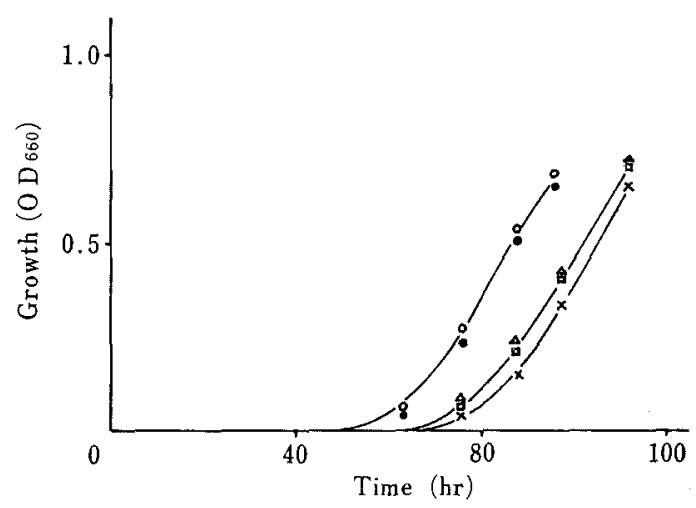

FIG. 7. Effect of PA, RL and Cultural Fluid on the Growth of $P$ s. aeriginosa $\mathrm{S}_{7} \mathrm{~B}_{1}$.

The cultivation was carried out in a shaking flask $(500 \mathrm{ml})$. All other conditions are described in the text. Carbon source: $1 \%(\mathrm{v} / \mathrm{v}) n$-hexadecane.

- - twenty-five $\mathrm{ml}$ of cultural fluid containing $\left.5 \mu \mathrm{g}^{a}\right) / \mathrm{ml}$ of PA and $0.5 \mu \mathrm{g} / \mathrm{ml}$ of $\mathrm{RL}$, which was obtained from the broth cultivated on $n$-hexadecane for $\left.63 \mathrm{hr} ; \mathrm{O}-\mathrm{O}, 125 \mu \mathrm{g}^{a}\right)$ of PA and $12.5 \mu \mathrm{g}$ of RL; $\triangle-\triangle, 125 \mu \mathrm{g}^{a}$ ) of PA heated at $98^{\circ} \mathrm{C}$ for $45 \mathrm{~min}$ and $12.5 \mu \mathrm{g}$ of RL; $\square-\square, 12.5 \mu \mathrm{g}$ of RL; $x-x$, none.

a) Human serum albumin equivalent.

oxidation capacity in EDTA-treated cells (Fig. 6) and could not exert the stimulating effect on the growth of the strain on the $n$ hexadecane medium (Figs. 7, 8). Taking into account the role of $\mathrm{PA}$ as an emulsifier or 


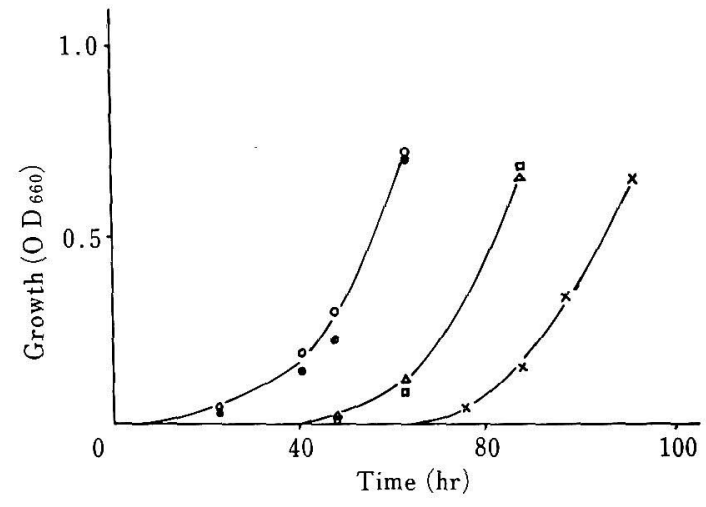

FIG. 8. Effect of PA, RL and Cultural Fluid on the Growth of $P_{S}$. aeruginosa $\mathrm{S}_{\bar{i}} \mathrm{~B}_{1}$.

The cultivation was carried out in a shaking flask $(500 \mathrm{ml})$. All other conditions are described in the text.

Carbon source: $1 \%(\mathrm{v} / \mathrm{v}) n$-hexadecane.

- - twenty-five $\mathrm{ml}$ of cultural fluid containing $\left.30 \mu \mathrm{g}^{a}\right) / \mathrm{ml}$ of PA and $1.5 \mu \mathrm{g} / \mathrm{ml}$ of $\mathrm{RL}$, which was obtained from the broth cultivated on $n$-hexadecane for $82 \mathrm{hr}$; O- $-750 \mu \mathrm{g}^{a)}$ of PA and $37.5 \mu \mathrm{g}$ of $\mathrm{RL}$; $\left.\triangle-\Delta, 750 \mu \mathrm{g}^{a}\right)$ of PA heated at $98^{\circ} \mathrm{C}$ for $45 \mathrm{~min}$ and $37.5 \mu \mathrm{g}$ of RL; $\square-\square, 37.5 \mu \mathrm{g}$ of RL; $\times-\times$, none.

a) Human serum albumin equivalent.

emulsion stabilizer, the emulsifying power of native and the heat-treated PA was tested in the presence of rhamnolipid. As shown in Fig. 9, the PA heated at $98^{\circ} \mathrm{C}$ for 45 min almost lost the emulsifying power on $n$-hexadecane.

While the interaction among PA, fine droplets of $n$-alkanes and bacterial cell surface must be taken into account, the significant role of PA can be regarded as forming fine droplets of $n$-alkanes based on the results of this paper.

It is thought that more detailed studies on the role of PA is helpful to clarify the mechanism of transport of water-insoluble substrates in bacteria. The results will be reported in further detail in a subsequent paper.

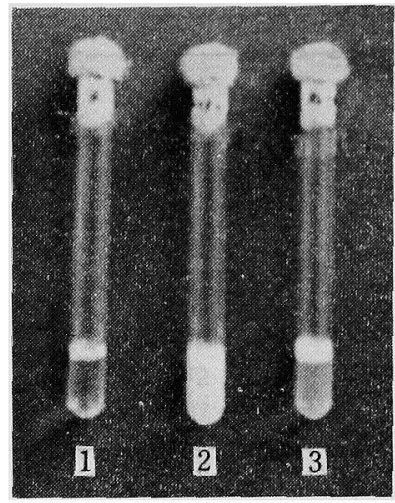

FIG. 9. Interaction ketween PA and Rhamnolipid on Emulsification.

After test tubes containing $9 \mathrm{ml}$ of the basal medium ${ }^{2}$ ) and $0.1 \mathrm{ml}$ of $n$-hexadecane were instantaneously sterilized at $120^{\circ} \mathrm{C}, 0.5 \mathrm{ml}$ of distilled water No. 1 , $0.5 \mathrm{ml}$ of PA solution $\left.\left(1.6 \mathrm{mg}^{a}\right) / \mathrm{ml}\right)$ No. 2 and $0.5 \mathrm{ml}$ of heat-treated PA solution $\left(1.6 \mathrm{mg}^{a} / \mathrm{ml}\right)$ No. 3, which were filtrated on a Millipore membrane filter (pore size $=0.22 \mu$ ), were respectively added. Shaking was carried out for $18 \mathrm{hr}$ on a reciprocal shaker.

a) Human serum albumin equivalent.

\section{REFERENCES}

1) K. Hisatsuka, T. Nakahara and K. Yamada, Abstracts of Papers, Annual Meeting of Agric. Chem. Soc. Japan, Tokyo, April, 1971, p. 141.

2) K. Hisatsuka T. Nakahara and K. Yamada, Agric. Biol. Chem., 36, 1361 (1972).

3) K. Hisatsuka, T. Nakahara, Y. Minoda and K. Yamada, ibid., 39, 999 (1975).

4) T. Nakahara, K. Hisatsuka and K. Yamada, J. Fermen. Assoc. Japan, 26, 418 (1968).

5) "Shishitsu Jikkenho," Kyoritsu Shuppan Co., Ltd., 1967, p. 108.

6) P. Andrews, Biochem. J., 91, 222 (1964).

7) S. Moore, J. Biol. Chem., 238, 235 (1963).

8) W. L. Bencze and K. Schmid, Anal. Chem., 29, 1193 (1957).

9) J. R. Spies and R. C. Cahmters, ibid., 21, 1249 (1949).

10) K. Hisatsuka, T. Nakahara, N. Sano and K. Yamada, Agric. Biol. Chem., 35, 686 (1971). 